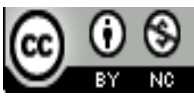 \\ Jurnal Terapan Manajemen dan Bisnis is licensed under \\ A Creative Commons Attribution-Non Commercial 4.0 International License.
}

\title{
THE EFFECT OF WORD OF MOUTH (WOM) ON PURCHASING DECISION OF REGION EXCLUSIVE FABRIC OF WEST NUSA TENGGARA PROVINCE (CASE STUDY ON SASAMBO FABRIC IN BIMA CITY)
}

\author{
Sri Ernawati1), Muhajirin'2), Ismunandar ${ }^{3)}$
}

1) Sekolah Tinggi Ilmu Ekonomi (STIE) Bima, Bima, Indonesia

E-mail: sriernawati.stiebima@gmail.com

2) Sekolah Tinggi Ilmu Ekonomi (STIE) Bima, Bima, Indonesia

E-mail: sriernawati.stiebima@gmail.com

3) Sekolah Tinggi Ilmu Ekonomi (STIE) Bima, Bima, Indonesia

E-mail: sriernawati.stiebima@gmail.com

\begin{abstract}
Word of mouth (WOM) become an important part in marketing studies considering that communication in Word of mouth (WOM) is able to influence the consumer. Word of mouth (WOM) is capable of spreading rapidly when the individual who is spreading it also has a wide network. This study aims to (1) to find out and analyze the positive and significant effect of Word of Mouth (WOM) on purchasing decision of region-exclusive fabric of West Nusa Tenggara Province (case study on Sasambo fabric in Bima City), (2) to give an input of thought to sasambo fabric manufacturer in Bima Town to implement the marketing strategy that does not rely on high cost but what is required is loyal consumer, so that the quality of sasambo fabric is must be upgraded and has more variety in motif. The research is conducted in Bima town for 2 months from Mei to June 2018. The population of this research is all of the people in Bima who bought and used Sasambo cloth with a number of samples are 96 people and technique of sampling is purposive sampling. The technique of Data analysis used is a simple linear regression analysis by using the equation, i.e: $Y=a+b x$. The result variable statistic test of WOM achievement point in the amount of 17.541 with table point in the amount of 1,985 (17.541 >1,985), then, so Word of Mouth (WOM) has a positive and significant effect on purchasing decision of region-exclusive fabric of West Nusa Tenggara province (Case Study on Sasambo Fabric in Bima City).
\end{abstract}

Keywords: Word of mouth (WOM); Purchasing Decision; Fabric

\section{Introduction}

In the middle of increasing conventional costs as like as television advertisement and print advertisement, the marketer can do other marketing activities basically still encouraging sales increase, one of them by using the strategy of Word of Mouth (WOM). So word of mouth marketing which is often seen in society that was called as Word of Mouth (WOM). The simple marketing doesn't need a big cost but very effective. Moreover with the behavior 
of Asian especially Indonesia which likes to mutual cooperation and socialize to talk about things they like (Yuliana, 2013).

Word of mouth Marketing is a marketing activity that triggers consumers to discuss, promote, recommend to sell brands of a product to other potential customers (Sumardy, 2011: 71). The occurrence of word of mouth triggers new potential customers to make purchases in a product that they have heard from other people. When prospective customers already know about the product that has been offered through promotion or get information from mouth to mouth, then prospective customers have the right to take consideration before they decide on a decision in the purchase (Nugraha, 2015).

In development along with the establishment of batik as a world cultural heritage by UNESCO, West Nusa Tenggara government moved to develop batik. On 17 April 2010 batik/'sasambo' fabric was launched this is an acronym of the three major tribes in NTB that was Sasak (Lombok Island), samawa (West Sumbawa districts and Sumbawa districts), and Mbojo (Bima and Dompu). This is with the aim that each tribe in NTB feels that they have characteristic and preserve the use of Sasambo fabric (Armea, 2013). Sasambo cloth has four main motives, as well as a variety of combinations, including Sasambo motifs, Mada Sahe motif (in Indonesian mean Mata Sapi), Kakando motifs, and Uma Lengge motif, whose motives are similar to small houses with conical domes. The style and color of Sasambo batik are in accordance with the local culture from each ethnic.

Using sasambo fabric has become an ordinary sight besides there is a recommendation from Bima town major that every Friday must wear traditional NTB fabrics such as Sasambo or even traditional Bima fabrics such as samarai, ngoli and others. But the reality now is not all employees use traditional NTB cloth or traditional Bima fabric, many employees are still using traditional fabrics from other areas such as rangrangbali, songket, ulos, batik and others which if seen their motifs almost resemble fabric - traditional NTB fabrics or traditional Bima fabric that are sasambo fabric.

This study aims to (1) find out and analyze the positive and significant effect of Word of Mouth (WOM) on purchasing decision of region-exclusive fabric of West Nusa Tenggara Province (case study on Sasambo fabric in Bima City) (2) to give an input of thought to sasambo fabric manufacturer in Bima Town to implement the marketing strategy that does not rely on high cost but what is required is loyal consumer, so that the quality of sasambo fabric is must be upgraded and has more variety in motif.

\section{Research Methods}

The type of research used in this study is using associative research. The population in this study were all the people of Bima City who had bought and used Sasambo fabric. The samples in this study were 96 people. The variables in this study are word of mouth (WOM) as an independent variable $(\mathrm{X})$ and a purchasing decision as a dependent variable $(\mathrm{Y})$ with several indicators as a benchmark to see the effect between variables $\mathrm{X}$ and variable $\mathrm{Y}$. Measurement of variables using likers scale (Sugiyono, 2010).

Data collection techniques used in this study, namely (1) Questionnaire, (2) Observation, (3) Literature study. the data using validity test by stating that if the validity of each statement is greater than 0.30 or $>0.30$ then the question item is considered valid and reliability testing is determined by the Cronbach's Alpha coefficient by requiring a reliable instrument if it has a Cronbach's Alpha coefficient above 0.60 or $>0.60$ (Ghozali, 2005). The data analysis technique used is a simple linear regression analysis using the equation, $\mathrm{Y}=\mathrm{a}+$ bx. 
To test the significance of the effect of the independent variable on the dependent variable, the t-test is performed on the regression coefficient (b). The hypothesis in t-test is $\mathrm{H} 0$, meaning that there is no significant effect on $\mathrm{Y}$, while $\mathrm{H} 1$ means that variable $\mathrm{X}$ has a significant effect on $\mathrm{Y}$. H0 is rejected and $\mathrm{H} 1$ is accepted if the value of $t$ counts more than $t$ table ( $t$ hit $>t$ tab). In regression analysis and $t$-test, this is done using SPSS 16 for windows. Against the variables, correlation analysis is performed to determine the shape and strength of the relationship of the independent variables to the dependent variable.

\section{Results and Discussion}

Validity test

Table 1 Validity Test Results

\begin{tabular}{ccccc}
\hline Item & r. Var count $\mathbf{X}$ & r. Var count $\mathbf{Y}$ & r. Tabel & Information \\
\hline 1 & 0.456 & 0.545 & 0.300 & Valid \\
2 & 0.579 & 0.656 & 0.300 & Valid \\
3 & 0.498 & 0.597 & 0.300 & Valid \\
4 & 0.428 & 0.564 & 0.300 & Valid \\
5 & 0.490 & 0.599 & 0.300 & Valid \\
6 & 0.574 & 0.670 & 0.300 & Valid \\
7 & 0.559 & 0.646 & 0.300 & Valid \\
8 & 0.517 & 0.628 & 0.300 & Valid \\
9 & 0.397 & 0.504 & 0.300 & Valid \\
10 & 0.558 & 0.711 & 0.300 & Valid \\
11 & & 0.629 & 0.300 & Valid \\
12 & & 0.625 & 0.300 & Valid \\
\hline
\end{tabular}

Based on Table 1 The results of testing the validity of the WOM variable on the Purchase Decision can be said to be valid in Corrected item-total correlation $>0.300$. The results of this validity test indicate that the questionnaire statement in this study is valid.

Reliability Test

Table 2 Reliability Test Results

\begin{tabular}{ccc}
\hline Variable & Cronbach Alpha & Information \\
\hline WOM $(\mathrm{X})$ & .675 & Reliable \\
Purchase Decision $(\mathrm{Y})$ & .838 & Reliable
\end{tabular}

Based on Table 2 the results of testing the study using this measurement can be said to be reliable in Cronbach alpha $>0.600$. The reliability testing results show that the questionnaire statement in this study is reliable.

Simple Linear Regression

Simple regression analysis was chosen to analyze the submission of hypotheses in this study. Testing is done using the SPSS 16.00 program for Windows.

Table 3 Results of Regression Coefficients ${ }^{a}$

\begin{tabular}{|c|c|c|c|c|c|}
\hline \multirow[t]{2}{*}{ Model } & \multicolumn{2}{|c|}{$\begin{array}{l}\text { Unstandardized } \\
\text { Coefficients }\end{array}$} & \multirow{2}{*}{$\begin{array}{c}\text { Standardized } \\
\text { Coefficients } \\
\text { Beta } \\
\end{array}$} & \multirow[t]{2}{*}{$\mathbf{t}$} & \multirow[t]{2}{*}{ Sig. } \\
\hline & B & Std. Error & & & \\
\hline (Constant) & 1.784 & 2.738 & & .652 & .516 \\
\hline WOM & 1.174 & .067 & .875 & 17.541 & .000 \\
\hline
\end{tabular}

a. Dependent Variable: Purchasing Decision 
From the results of regression analysis can be seen as a simple linear regression equation as follows: $\mathrm{Y}=1.784+1.174 \mathrm{X}$

Based on these equations, it can be explained as follows:

a. The constant value of 1.784 can be interpreted if the word of mouth (WOM) variable is considered zero, then the Purchase Decision will be 1.784 .

b. The beta coefficient value on the word of mouth (WOM) variable is 1.174, meaning that every change in the WOM variable $(X)$ is one unit, it will result in a change in Purchase Decision $(\mathrm{Y})$ of 1.174 units, with other assumptions being fixed.

\section{Correlation Test}

Correlation analysis is simple to find out the degree or strength of the relationship between two variables. Simple correlation test can be done using SPSS 16.0 for Windows data processing application program.

Table 4 Result of correlation Model Summary

\begin{tabular}{lrrrr}
\hline Model & R & R Square & $\begin{array}{c}\text { Adjusted R } \\
\text { Square }\end{array}$ & $\begin{array}{l}\text { Std. Error of } \\
\text { the Estimate }\end{array}$ \\
\hline 1 & $.875^{\mathrm{a}}$ & .766 & .763 & 2.672 \\
\hline a. Predictors: (Constant), WOM & & &
\end{tabular}

Based on the table of the results of a simple correlation test, it can be explained the correlation between the variable word of mouth (WOM) $(\mathrm{X})$ on the Purchase Decision $(\mathrm{Y})$ as follows: Ryx $=$ There is a correlation or relationship between word of mouth (WOM) $(X)$ and Purchase Decision $(\mathrm{Y})$ with a correlation value of 0.875 . This relationship can qualitatively be expressed as a strong relationship level in accordance with the guidance table of the correlation coefficient interval (Sugiyono, 2008).

Determination Coefficient Test

\begin{tabular}{lcccr}
\multicolumn{4}{c}{ Table 5 Result of Determination Model Summary } \\
\hline Model & $\mathbf{R}$ & R Square & $\begin{array}{c}\text { Adjusted R } \\
\text { Square }\end{array}$ & $\begin{array}{c}\text { Std. Error of } \\
\text { the Estimate }\end{array}$ \\
\hline 1 & $.875^{\mathrm{a}}$ & .766 & .763 & 2.672 \\
\hline a. Predictors: (Constant), WOM & & &
\end{tabular}

The test results of adjusted R2 in this study obtained a value of 0.766 . This shows that the Purchasing Decision is influenced by word of mouth (WOM) by $76.6 \%$, while the remaining $23.4 \%$ is influenced by other factors not included in this study.

\section{Hypothesis Test Results}

Furthermore, to find out whether the hypothesis proposed in this study is accepted or rejected, hypothesis testing will be conducted using the t-test. The results of testing the hypothesis are explained as follows:

Table 6 Results t-test Coefficients ${ }^{a}$

\begin{tabular}{|c|c|c|c|c|c|}
\hline \multirow[t]{2}{*}{ Model } & \multicolumn{2}{|c|}{$\begin{array}{l}\text { Unstandardized } \\
\text { Coefficients }\end{array}$} & \multirow{2}{*}{$\begin{array}{c}\text { Standardized } \\
\text { Coefficients } \\
\text { Beta } \\
\end{array}$} & \multirow[t]{2}{*}{$\mathbf{t}$} & \multirow[t]{2}{*}{ Sig. } \\
\hline & B & Std. Error & & & \\
\hline (Constant) & 1.784 & 2.738 & & .652 & .516 \\
\hline WOM & 1.174 & .067 & .875 & 17.541 & .000 \\
\hline
\end{tabular}

a. Dependent Variable: Purchasing Decision 
The results of the t-test statistic for the WOM variable obtained count 17.541 with a ttable value of 1.985 (17.541 > 1.985) with a significance value of 0.000 smaller than $0.05(0.000$ $<0.05$ ), the hypothesis stating that "word of mouth (WOM) has a positive and significant effect on the decision to purchase fabrics typical of West Nusa Tenggara Province (Case study on Sasambo fabric in Bima City) "Accepted". This is in accordance with the results of the research by Finanda \& Wiwaha (2017) showing that word of mouth has a positive and significantly significant effect on the decision to use the Miloff Beauty Bar and by Andari \& Napu (2016) stated that word of mouth had an effect on the decision to buy domestic airline tickets.

\section{Conclusion}

The people of Bima City already know and use traditional NTB fabrics, Sasambo fabrics. This can be evidenced by research conducted by researchers, where word of mouth (WOM) has a positive and significant effect on the decision to purchase fabrics typical of West Nusa Tenggara Province (case study on Sasambo fabric in Bima City). While the motif of Sasambo fabric produced by the sasambo fabric producer in Bima City has varied according to market demand.

\section{Reference}

Andari, R., \& Napu, M. Della. 2016. Pengaruh Word of Mounth terhadap Keputusan Pembelian Tiket Maskapai Penerbangan Domestik di Davina Tour and Travel Gorontalo. Jurnal Tourism and Hospitality essentials (THE), 4(1).

Armea. (2013). Cultur of Indonesia. (Accessed on February 20, 2016).

Finanda, R. Iknesya., \& Wiwaha Arjuna. 2017 . Pengaruh Word of Mounth dan brand Image terhadap keputusan penggunaan salon kecantika pada konsumen Miloff Beauty Bar. Jurnal Ilmiah WIDYA Ekonomika, 1(2), 134-140.

Ghozali, Imam. 2005. Aplikasi Analisis Multivariate Dengan Program SPSS. Edisi Ketiga. Semarang: Badan Penerbit Universitas Diponegoro

Nugraha, A.A., Finna, Suhardyono., \& Kusumawati, A. (2015). Pengaruh terhadap Keputusan Pembelian dan Kepuasan Konsumen (Studi Kasus pada Konsumen Kober Mie Setan Jalan Simpang Soekarno-Hatta No. 1-2 Malang). Jurnal Administrasi Bisnis (JAB), 22(1).

Sugiyono.(2010). Metode Penelitian Administrasi. Bandung: Alfabeta.

Sumardy, Marlin, Silviana., \& Melina, Melone. (2011). The Power of Word of Mouth Marketing. Cetakan Kedua. Jakarta: PT. Gramedia Pustaka Utama.

Yuliana, Rahmi. (2013). Analisis Strategi WOM untuk Meningkatkan Keputusan Pembelian pada Konsumen di Kota Semarang. Jurnal STIE Semarang, 5(3). 